\title{
Measuring Leagile Supply Chain, Information Sharing, and Supply Chain Performance: Pre-Test and Pilot Test
}

\author{
Susan Sabah Abdulameer ${ }^{1}$, Noorulsadiqin Azbiya Yaacob ${ }^{1 *}$, Yousif Munadhil Ibrahim ${ }^{1}$ \\ ${ }^{1}$ School of Technology Management and Logistics, College of Business, Universiti Utara Malaysia, Kedah \\ 06010, Malaysia
}

\begin{abstract}
The aim of the current paper is to provide a valid and reliable instrument to ensure accurate results. Studies published on the supply chain and leagile supply chain (LASC) and information sharing (IS) as well as their impacts on supply chain performance (SCP) were reviewed, the measurements of the dimensions were adapted and developed, and the validity and reliability for the measures of the LASC, IS, and SCP dimensions were assessed. This assessment was done in two tests: the pre-test to establish the validity of the measures by experts and the pilot test to check the reliability of the measurements using SPSS.V.25. In the pre-test, the comments made by seven academician experts and four practitioners were used to rephrase items and to modify them according to the requirements of the manufacturing industries and in accordance with the Iraq context. Moreover, in the pilot test, some important factors were identified: on average, respondents took about 15 to 20 minutes to complete the questionnaire, and all the items were reliable and were sufficiently correlated with their constructs. The paper focuses on providing valid and reliable measurements for LASC, IS, and SCP as well as the developed measurements used for the decoupling point and testing them.
\end{abstract}

Keywords: Decoupling point; Information sharing; Leagile supply chain; Pre-test, Pilot test; Supply chain performance

\section{Introduction}

Currently, competition occurs more often for supply chains than individual companies. In other words, the highest competition is between supply chains (Koh et al., 2006) because supply chain management focuses on the flows of materials, information, and cash from suppliers to customers, or vice-versa (Wibowo and Sholeh, 2015). In fact, companies are facing a series of challenges and issues, most notably the need to balance SCP elements, which involves cost reduction and quick responsiveness while ensuring high quality and a short lead time in a volatile market environment with unexpected demands. Moreover, to counteract uncertainty, companies in the manufacturing industry in Iraq require a suitable supply chain strategy (SCS) to manipulate and to exploit opportunities. In addition, the flow of materials, information, and cash requires a good information system capable to share information among supply chain partners, including suppliers, manufacturers, distributors, and customers, to reduce uncertainty and to improve SCP (Dachyar et al., 2015). Thus, manufacturing companies must develop a strategy that suits their products, markets, and

\footnotetext{
*Corresponding author's email: noorulsadiqin@gmail.com, Tel.: +60195929107 or +6049286992; Fax: +6049287070

doi: 10.14716/ijtech.v11i4.3496
} 
target customers (Mason-Jones et al., 2000; Nurcahyo and Kristihatmoko, 2010; Hallavo, 2015).

The manufacturing industry supply chain is an important issue for all countries. The UN Bulletin of Industrial Statistics for Arab Countries ESCWA's (2016) report pointed out that manufacturing industries play an important role in gross domestic product (GDP); however, in Iraq, there is a reversed trend due to the dependence on mining and quarrying. The contribution of the manufacturing industries in oil-producing countries has fallen to less than five percent, such as in Iraq, due to the heavy reliance on oil production and weak supply chain management (Al-Mehannah, 2019); however, AIDMO's (2017) report stated that manufacturing industries positively contributed to the growth rate of the real GDP per country, except for Iraq, which was negative at $-2.4 \%$ due to the decline in the share of manufacturing industries in the GDP amounting to 3.8\%, indicating the weakness of the manufacturing industry in Iraq. The role of the manufacturing industry is crucial and strategic as one of the main drivers of GDP (Putri et al., 2016).

Simultaneously, the manufacturing industry supply chain in Iraq is still suffering from many problems, which have increased in the last few years, such as a rise in costs due to wasted resources and energy, contributing to a rise in product prices (Al-Mehannah, 2019; Salim et al., 2019). In addition, there are mismatching products with specifications that have been determined in previous (Aljalely and Alsammak, 2019). In addition, the manufacturing industry in Iraq faces another problem, which is the length of lead time from order to delivery. There is also a weakness in the ability to respond to customers' demands and desires. These issues cause a weak SCP.

Naylor et al. (1999) identified three supply chain strategies (SCSs) that are lean, agile, and leagile. Indeed, a lean strategy and an agile strategy are common strategies in supply chains. From a more comprehensive perspective, the aim of the Leagile Supply Chain (LASC) is to combine the advantages of lean and agile strategies by improving, cost, quality, lead time, and responsiveness (Nakandala and Lau, 2019). In addition, a focus of the LASC is to satisfy customers and to achieve competitive advantages distinguishing some manufacturers from others. Hence, a successful LASC improves the SCP.

Moreover, the LASC dimensions require the lean supply chain (LSC), the agile supply chain (ASC), the decoupling point (DP), and postponement (POS) to function properly and harmoniously, and there should be information sharing with a suitable quality and relevant level among the supply chain partners as this plays an essential role in improving the SCP, including supply chain cost (SCC), supply chain quality (SCQ), supply chain lead time (SCLT), and supply chain responsiveness (SCR).

The importance and novelty of this study is that the four variables of the LASC have not been analyzed together in a previous study. The measurements of the present study's variables and dimensions were adapted from previous studies with the exception of the measurements of the DP dimension, which were developed specifically for this study. According to Creswell and Creswell (2018), in quantitative studies, when there is any adaptation or development of one or more measurements, the prior validity and reliability may not apply to the new measurements. Therefore, the validity and the reliability of the measurements of LASC, IS, and SCP among the manufacturing industry companies in Iraq are evaluated.

Given that the supply chain and its performance are of interest to researchers and practitioners, the present research will be of great importance to the literature and industries. It will provide valid and reliable measurements for academicians. The present research will also provide many practical managerial implications to solve the SCP problems faced by the manufacturing industry. 


\section{Methodology}

The context of the present study includes the manufacturing industry in Iraq, which includes manufacturing industry companies registered in the Ministry of Planning in Iraq. The success of this industry is important to the GDP as the value added by the manufacturing industry in Iraq for the year 2015 amounted to about \$5519 million (AIDMO, 2017), which represents 3.8\% of the GDP for the same year. The targeted respondents were persons at the executive and managerial levels and above due to their close relation and involvement with the SCS.

Measures from previous studies have been adapted to the variables and dimensions of the present study. The DP measure has been developed based on an extensive literature review search to generate the items, and the content validity was ensured through the opinions of practitioner experts and academician experts. After completing the content and face validity processes, the instrument testing step was performed. The questionnaire was distributed to a small sample of respondents to gain an initial indication of the validity and reliability analysis. Based on the results of the reliability test, any item that did not contribute to the reliability of scales was excluded. In other words, the pre-test was conducted to verify the face validity (Hair et al., 2013). Then, the pilot test was carried out to establish the reliability of the measurements used (Saunders et al., 2016).

The scaling design of the items was measured on a six-point Likert scale: "1" = "Strongly Disagree" (SD); "2" = "Moderately Disagree" (MOD); "3" = "Slightly Disagree" (SLD); "4" = "Slightly Agree" (SLA); "5" = "Moderately Agree" (MOA); and "6" = "Strongly Agree" (SA). The reason for using the six-point Likert scale was to ensure that participants did not simply check the "indifference" choice or "midpoint," which commonly occurs with a five-point scale. The midpoint refers to the neutral response when answering a questionnaire with an odd number of categories used for a scale (Hair et al., 2017a). It has also been emphasized that researchers usually use a scale without a midpoint when many respondents are expected to choose neutral responses to a particular issue because it is an easy option that requires little effort and is easily justified (Krosnick and Fabrigar, 1997). According to (Garland, 1991), the presence of a five-point Likert scale with a middle point of " 3 " "neither agree nor disagree" will interfere with the findings of a study due to social desirability bias, and he further argued that the participants would answer based on the content of the questions when given an even number response scale. In addition, participants from Asian countries tend to choose the middle category response more often than those from Western countries (Ong et al., 2015). It was also found that the validity and reliability of findings tend to be higher for an even number response scale and for a six-point scale in particular (Chomeya, 2010) when compared with the odd number response scale (Krosnick and Fabrigar, 1997). The questionnaire consisted of four parts: the first part focused on the LASC, the second part the IS, the third part the SCP, and the fourth part. The profile of the company and person. Figure 1 illustrates the methodology process.

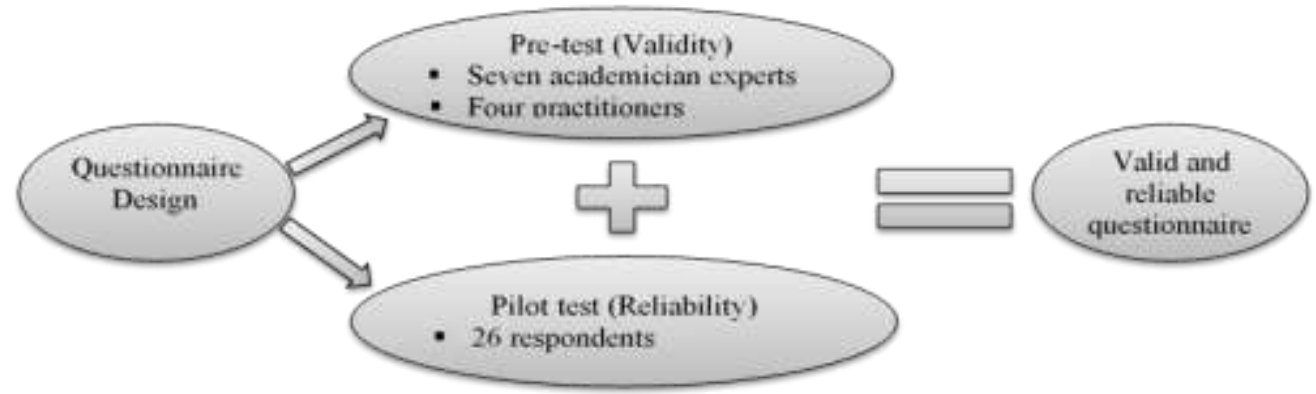

Figure 1 Methodology process 


\section{Results and Discussion}

\subsection{Pre-test (Validity)}

The pre-test process involved face validity. Face validity is determined through a systematic assessment of the measurement based on the subjective judgment of experts (Hair et al., 2013) to verify the measurements' ability to measure what they are meant to measure in the study (Hair et al., 2017b). They also pointed out that this validation method is commonly used in management and business research. Therefore, the study measurements that were adapted from previous studies for the independent variable (i.e., leagile supply chain), dependent variable (i.e., supply chain performance), and moderating variable (i.e., information sharing) were sent to seven experts familiar with the constructs of this study to determine the face validity of the measurements. These experts were from the Universiti Utara Malaysia, the National Institute of Technology, Warangal, the New York Institute of Technology, and The American University in Cairo. In addition, four manufacturing industry practitioners were contacted for the same purpose. Their feedback, recommendations, and comments (see Table 1) were subsequently incorporated into the final draft of the instrument.

Table 1 Results of face validity by experts in the pre-test

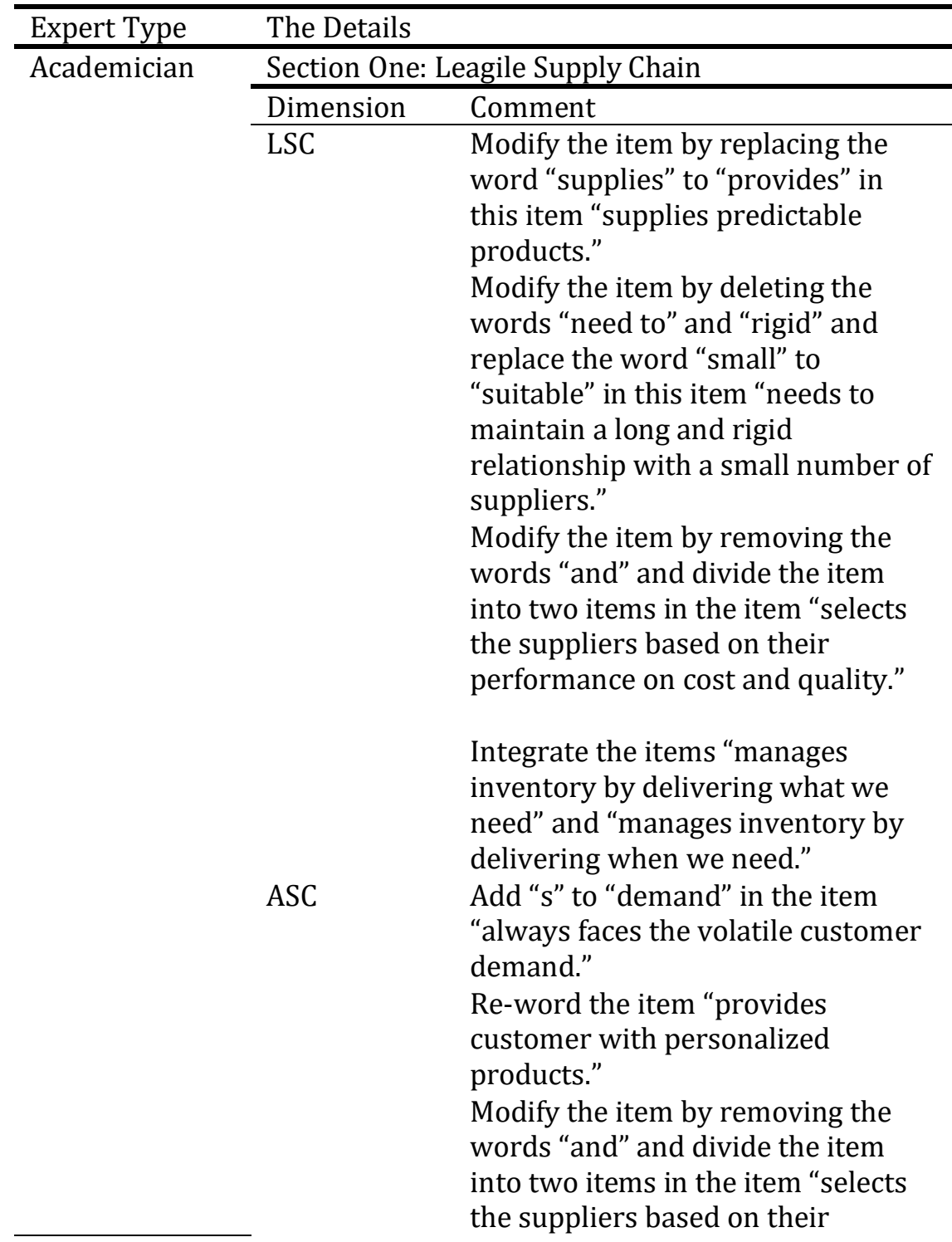

Action
Provides predictable
products

products

Maintain a long relationship with a suitable number of suppliers

Select the suppliers based on their performance on cost

Select the suppliers based on their performance on quality

Manage the inventory we need by delivering it when we need it

Always faces the volatile customer demands

Provides personalized products for the customer

Selects the suppliers based on their performance on flexibility 


\begin{tabular}{|c|c|c|c|}
\hline Expert Type & \multicolumn{3}{|l|}{ The Details } \\
\hline & \multirow{4}{*}{ POS } & $\begin{array}{l}\text { performance on flexibility and } \\
\text { responsiveness." }\end{array}$ & $\begin{array}{l}\text { Selects the suppliers based } \\
\text { on their performance on } \\
\text { responsiveness }\end{array}$ \\
\hline & & $\begin{array}{l}\text { Re-word this item "structure often } \\
\text { changes in order to cope with } \\
\text { volatile market." }\end{array}$ & $\begin{array}{l}\text { Often changes its structure } \\
\text { to cope with the volatile } \\
\text { market }\end{array}$ \\
\hline & & $\begin{array}{l}\text { Modify the item by removing the } \\
\text { words "and" and divide the item }\end{array}$ & $\begin{array}{l}\text { Can re-arrange the } \\
\text { production process }\end{array}$ \\
\hline & & $\begin{array}{l}\text { into two items. In this item, } \\
\text { "production process can be re- } \\
\text { arranged, and some processes can } \\
\text { be carried out later at distribution } \\
\text { centers." }\end{array}$ & $\begin{array}{l}\text { Can carry out some } \\
\text { processes later at } \\
\text { distribution centers }\end{array}$ \\
\hline & \multicolumn{3}{|c|}{ Section Two: Information Sharing } \\
\hline & Dimension & Comment & Action \\
\hline & \multirow[t]{2}{*}{ LIS } & $\begin{array}{l}\text { Modify the item by removing the } \\
\text { word "will" in the item "will keep } \\
\text { us fully informed if there are any } \\
\text { issues that might affect our } \\
\text { company." }\end{array}$ & $\begin{array}{l}\text { Keep us fully informed if } \\
\text { there are any issues that } \\
\text { might affect our company }\end{array}$ \\
\hline & & $\begin{array}{l}\text { Modify the item by removing the } \\
\text { words "Our partners" in the item } \\
\text { "Our partners share their } \\
\text { knowledge to develop our core } \\
\text { company processes." }\end{array}$ & $\begin{array}{l}\text { Share their knowledge to } \\
\text { develop our core company } \\
\text { processes }\end{array}$ \\
\hline & \multicolumn{3}{|c|}{ Section Three: Supply Chain Performance } \\
\hline & Dimension & Comment & Action \\
\hline & SCC & $\begin{array}{l}\text { Delete the item "prices as low or } \\
\text { lower than our competitors" } \\
\text { because it is similar to other items. }\end{array}$ & Done \\
\hline & SCQ & $\begin{array}{l}\text { Re-word the item "customers are } \\
\text { satisfied." }\end{array}$ & Has satisfied customers \\
\hline & SCLT & $\begin{array}{l}\text { Re-word the item "was getting a } \\
\text { shorter length of the supply chain } \\
\text { process." }\end{array}$ & $\begin{array}{l}\text { Has a supply chain process } \\
\text { as short as possible }\end{array}$ \\
\hline & SCR & $\begin{array}{l}\text { Re-word the item "the ability to } \\
\text { produce products characterized by } \\
\text { numerous features." }\end{array}$ & $\begin{array}{l}\text { The ability to produce } \\
\text { products with multiple } \\
\text { features }\end{array}$ \\
\hline & & $\begin{array}{l}\text { Re-word the item "shortened and } \\
\text { more complex product life cycles." }\end{array}$ & $\begin{array}{l}\text { The ability to produce } \\
\text { products with a short life } \\
\text { cycle. }\end{array}$ \\
\hline \multirow[t]{4}{*}{ Practitioners } & \multicolumn{3}{|c|}{ Section One: Leagile Supply Chain } \\
\hline & Dimension & Comment & Action \\
\hline & LSC & $\begin{array}{l}\text { Delete the item "structure seldom } \\
\text { changes" because we had asked } \\
\text { about the structure in the agile } \\
\text { supply chain dimension. }\end{array}$ & Done \\
\hline & ASC & $\begin{array}{l}\text { Delete the item "needs to maintain } \\
\text { a short and flexible relationship } \\
\text { with many suppliers" because we } \\
\text { had asked about the long } \\
\text { relationships in the lean supply } \\
\text { chain dimension. }\end{array}$ & Done \\
\hline
\end{tabular}




\begin{tabular}{llll}
\hline Expert Type & The Details & \\
\hline & $\begin{array}{l}\text { Delete the item "able to proactively } \\
\text { establish virtual manufacturing to } \\
\text { meet volatile market } \\
\text { requirements" because it is similar } \\
\text { to other items. }\end{array}$ & \\
\cline { 2 - 3 } & \multicolumn{2}{l}{ Section Three: Supply Chain Performance } & Action \\
\hline Dimension & Comment & $\begin{array}{l}\text { Delete the item "offers high-quality } \\
\text { products to our customers" } \\
\text { because it is similar to other items. } \\
\text { Delete the item "a fast customer } \\
\text { response time" because it is similar } \\
\text { to other items. }\end{array}$ & Done \\
\hline
\end{tabular}

\subsection{Pilot Study (Reliability)}

Generally, when constructing a study instrument, it is essential to conduct a pilot test before beginning the main study (Hair et al., 2014). This is to ensure that an accurate instrument will be used in the main study (Saunders et al., 2016). In addition, it serves as a sifting of the problems and obstacles that may appear in the main study. Moreover, according to Hair et al. (2014), when developing measurements or adapting from various sources, a pilot test should be conducted. Therefore, a pilot test was conducted because the measurements were adapted from other studies for all dimensions of the LASC, SCP, and IS with the exception of one dimension of the LASC, which is the DP.

Data collection for the current study began with a pilot study (Cooper and Schindler, 2014). Saunders et al. (2009) defined a pilot test as a "small-scale study to test a questionnaire, interview checklist or observation schedule, to minimize the likelihood of respondents having problems in answering the questions and of data recording problems as well as to allow some assessment of the questions' validity and the reliability of the data that will be collected." Most importantly, researchers conduct a pilot study for many essential purposes: (1) understanding each item from respondents (Sekaran and Bougie, 2010); (2) examining the accuracy and clarity of the wording (Kumar, 2011, p. 158); (3) estimating the time of completion by respondents (Adams et al., 2014); (4) helping to clarify the extent of the flow and sequences of items (Bryman and Bell, 2015); and (5) evaluating the validity of the items and the potential reliability of the data to be collected (Saunders et al., 2016). Thus, a pilot study eliminates weaknesses and flaws in the main study instrument.

Bell and Waters (2014) suggested giving the respondents a short questionnaire attached to the original questionnaire of the study including a set of questions to achieve these purposes:

1. How long did it take to complete the questionnaire?

2. Were the questionnaire's instructions clear?

3. Was any item of the questionnaire ambiguous or unclear? If yes, please say which and why.

4. Did you protest to answering any of the items?

5. In your evaluation, was any main topic neglected?

6. In your opinion, was the questionnaire design clear/attractive?

7. Further comments? 
Principally, a pilot study should be conducted with people who are similar to those to whom the questionnaire will be administered (Cooper and Schindler, 2014). In addition, the closer the match between the pilot sample and the main sample will be the more accurate results (de Vaus, 2013). It is also important that the environment in the pilot study is similar to the main study's environment for examining the items and ensuring their suitability (Hair et al., 2014). Accordingly, the questionnaire was distributed to a small sample of the total population. Malhotra (2010) suggested that the sample size should vary from 15-30 participants for the pilot test to identify the difficulties and weaknesses of the pilot test questionnaire. Consequently, a total of 36 questionnaires were distributed, and only 26 questionnaires were usable of 34 that were returned.

Reliable measurements achieve the same results on repeated occasions (de Vaus, 2013). Cronbach's alpha was used for this purpose based on the recommendations of a number of researchers (e.g., Saunders et al., 2016). Cronbach's alpha ranges from 0 to 1 with the lowest acceptance value of .70 (Hair et al., 2013). Moreover, the item analysis method was used for the Corrected Item-Total Correlation test to estimate the reliability of the responses to the instrument (Field, 2009) as well as to explain the most correlated items with the construct. If the value of any item was less than .30, it was deleted (Nunnally and Bernstein, 1994; Field, 2009). Using SPSS.V.25, the reliability of the measurements and the item analysis were analyzed (Field, 2013), as shown in Table 2. For more details about the items, see Appendix 1.

Table 2 Results of the reliability test in the pilot test

\begin{tabular}{|c|c|c|c|c|}
\hline Dimension & Item & $\begin{array}{l}\text { Corrected Item- } \\
\text { Total Correlation }\end{array}$ & $\begin{array}{l}\text { Cronbach's Alpha } \\
\text { if Item Deleted }\end{array}$ & $\begin{array}{c}\text { Cronbach's } \\
\text { Alpha }\end{array}$ \\
\hline \multicolumn{5}{|l|}{ Leagile Supply Chain (LASC) } \\
\hline \multirow[t]{8}{*}{ Lean Supply Chain (LSC) } & LSC.1 & .551 & .800 & .822 \\
\hline & LSC. 2 & .546 & .801 & \\
\hline & LSC. 2 & .574 & .797 & \\
\hline & LSC. 4 & .556 & .799 & \\
\hline & LSC.5 & .483 & .809 & \\
\hline & LSC.6 & .634 & .787 & \\
\hline & LSC.7 & .390 & .822 & \\
\hline & LSC.8 & .603 & .793 & \\
\hline \multirow[t]{8}{*}{ Agile Supply Chain (ASC) } & ASC. 1 & .645 & .808 & .836 \\
\hline & ASC. 2 & .354 & .841 & \\
\hline & ASC.3 & .565 & .817 & \\
\hline & ASC. 4 & .788 & .786 & \\
\hline & ASC. 5 & .746 & .791 & \\
\hline & ASC. 6 & .696 & .799 & \\
\hline & ASC.7 & .437 & .833 & \\
\hline & ASC. 8 & .340 & .848 & \\
\hline \multirow[t]{5}{*}{ Decoupling Point (DP) } & DP.1 & .460 & .755 & .759 \\
\hline & DP.2 & .660 & .663 & \\
\hline & DP.3 & .732 & .649 & \\
\hline & DP.4 & .518 & .720 & \\
\hline & DP.5 & .331 & .773 & \\
\hline \multirow[t]{6}{*}{ Postponement (POS) } & POS.1 & .560 & .827 & .842 \\
\hline & POS.2 & .587 & .823 & \\
\hline & POS.3 & .661 & .807 & \\
\hline & POS.4 & .733 & .793 & \\
\hline & POS.5 & .679 & .804 & \\
\hline & POS.6 & .504 & .837 & \\
\hline
\end{tabular}




\begin{tabular}{|c|c|c|c|c|}
\hline Dimension & Item & $\begin{array}{l}\text { Corrected Item- } \\
\text { Total Correlation } \\
\end{array}$ & $\begin{array}{l}\text { Cronbach's Alpha } \\
\text { if Item Deleted }\end{array}$ & $\begin{array}{c}\text { Cronbach's } \\
\text { Alpha }\end{array}$ \\
\hline \multicolumn{5}{|l|}{ Information Sharing (IS) } \\
\hline \multirow[t]{6}{*}{$\begin{array}{l}\text { Quality of } \text { Information } \\
\text { Sharing (QIS) }\end{array}$} & QIS.1 & .705 & .747 & .809 \\
\hline & QIS.2 & .509 & .792 & \\
\hline & QIS.3 & .651 & .760 & \\
\hline & QIS.4 & .452 & .803 & \\
\hline & QIS.5 & .673 & .755 & \\
\hline & QIS.6 & .431 & .809 & \\
\hline \multirow[t]{6}{*}{$\begin{array}{l}\text { Level of Information Sharing } \\
\text { (LIS) }\end{array}$} & LIS.1 & .557 & .671 & .735 \\
\hline & LIS.2 & .429 & .712 & \\
\hline & LIS.3 & .510 & .685 & \\
\hline & LIS.4 & .418 & .713 & \\
\hline & LIS.5 & .450 & .703 & \\
\hline & LIS.6 & .479 & .698 & \\
\hline \multicolumn{5}{|c|}{ Supply Chain Performance (SCP) } \\
\hline \multirow[t]{7}{*}{ Supply Chain Cost (SCC) } & SCC.1 & .870 & .842 & .882 \\
\hline & SCC. 2 & .561 & .879 & \\
\hline & SCC.3 & .625 & .872 & \\
\hline & SCC. 4 & .809 & .847 & \\
\hline & SCC.5 & .657 & .867 & \\
\hline & SCC.6 & .757 & .856 & \\
\hline & SCC.7 & .468 & .890 & \\
\hline \multirow[t]{7}{*}{ Supply Chain Quality (SCQ) } & SCQ.1 & .570 & .798 & .823 \\
\hline & SCQ.2 & .606 & .792 & \\
\hline & SCQ.3 & .670 & .782 & \\
\hline & SCQ.4 & .428 & .820 & \\
\hline & SCQ.5 & .652 & .784 & \\
\hline & SCQ.6 & .525 & .806 & \\
\hline & SCQ.7 & .512 & .808 & \\
\hline \multirow{7}{*}{$\begin{array}{l}\text { Supply Chain Lead Time } \\
\text { (SCLT) }\end{array}$} & SCLT.1 & .401 & .809 & .810 \\
\hline & SCLT.2 & .487 & .795 & \\
\hline & SCLT.3 & .685 & .763 & \\
\hline & SCLT.4 & .588 & .777 & \\
\hline & SCLT.5 & .539 & .786 & \\
\hline & SCLT. 6 & .725 & .751 & \\
\hline & SCLT.7 & .424 & .807 & \\
\hline \multirow{7}{*}{$\begin{array}{l}\text { Supply Chain Responsiveness } \\
\text { (SCR) }\end{array}$} & SCR.1 & .446 & .787 & .798 \\
\hline & SCR.2 & .489 & .779 & \\
\hline & SCR.3 & .691 & .742 & \\
\hline & SCR.4 & .451 & .786 & \\
\hline & SCR.5 & .677 & .744 & \\
\hline & SCR.6 & .524 & .775 & \\
\hline & SCR.7 & .448 & .785 & \\
\hline
\end{tabular}

Based on the pilot study feedback for the seven questions attached to the original questionnaire of the study (Bell and Waters, 2014), certain words were reconstructed to provide a better understanding for the respondents of the main survey. The pilot test also revealed that on average, respondents required about 15 to 20 minutes to complete the survey instrument. In addition, Table 3 shows that the results of reliability range from .735 to .882 , suggesting that all the Cronbach's alpha values were greater than .70 , which 
indicates that the 67 measurements were reliable (Hair et al., 2014). Based on the item analysis, all the items correlated higher than .30 for the Corrected Item-Total Correlation, which ranged from .331 to .870. This means that all items are correlated with their constructs. Therefore, all items have been retained without the need to delete any of them.

\section{Conclusions}

A valid and reliable instrument necessary to ensure accurate results when measuring LASC, IS, and SCP has been developed. Two tests were carried out for the present study: the pre-test to establish the validity of the measurements and the pilot test to check the reliability of the measurements. In the pre-test, the comments made by academician experts and practitioners were used to rephrase items and to modify them according to the requirements of the manufacturing industries and in accordance with the Iraqi environment. Moreover, in the pilot test, some important factors were identified: on average, respondents required about 15 to 20 minutes to complete the questionnaire, and all the items were reliable and were sufficiently correlated with their constructs. Therefore, valid and reliable measurements have been developed that can provide a better perception for researchers, policymakers, and top management, particularly in the manufacturing industry, regarding how to measure LASC, IS, and SCP. The future agenda of the authors is to conduct an empirical study using these variables in the manufacturing industry to investigate the relationships among them.

\section{References}

Adams, J., Khan, H.T.A., Raeside, R., 2014. Research Methods for Business and Social Science Students. $2^{\text {nd }}$ Edition. Los Angeles, USA: AGE Publications

AIDMO, 2017. Economic \& Indicators of Arab Countries. Retrieved from the Arab Industrial Development and Mining Organization

Al-Mehannah, H.G.M., 2019. The Role of Supply Chain Management in External Indebtedness and Its Problems in the Iraq Economy. International Journal of Supply Chain Management, Volume 8(2), pp. 691-704

Aljalely, A., Alsammak, M., 2019. Cognitive Transformation Reflections based on the Supply Chain Management and 5s Requirements (An Analytical Descriptive Study of a Sample of Workers in Zaki/Iraq Factory in the Province of Dohuk). International Journal of Supply Chain Management, Volume 8(3), pp. 426-434

Bell, J., Waters, S., 2014. Doing Your Research Project: A Guide for First-Time Researchers. $6^{\text {th }}$ Edition. New York, USA: McGraw-Hill Education

Bryman, A., Bell, E., 2015. Business Research Methods. 4th Edition. London, England, United Kingdom: Oxford University Press

Chomeya, R., 2010. Quality of Psychology Test between Likert Scale 5 and 6 Points. Journal of Social Sciences, Volume 6(3), pp. 399-403

Cooper, D., Schindler, P., 2014. Business Research Methods. 12 ${ }^{\text {th }}$ Edition. New York, USA: McGraw-Hill Higher Education

Creswell, J.W., Creswell, J.D., 2018. Research Design: Qualitative, Quantitative, and Mixed Methods Approaches. $5^{\text {th }}$ Edition. Los Angeles, USA: SAGE Publications

Dachyar, Yadrifil, M., Pratama, N.R., 2015. Development of Strategy Model for Organizational Innovation through Information Systems in Higher Education in Indonesia. International Journal of Technology, Volume 6(2), pp. 284-290

de Vaus, D.A., 2013. Surveys in Social Research. $6^{\text {th }}$ Edition. Routledge, USA: London and New York 
ESCWA, 2016. Bulletin of Industrial Statistics for Arab Countries (9). Retrieved from Economic and Social Commission for Western Asia.

Field, A., 2009. Discovering Statistics Using IBM SPSS Statistics. $3^{\text {rd }}$ Edition. London, United Kingdom: SAGE Publications

Field, A., 2013. Discovering Statistics Using IBM SPSS Statistics. $4^{\text {th }}$ Edition. London, United Kingdom: SAGE Publications

Garland, R., 1991. The mid-point on a rating scale: Is it desirable? Marketing Bulletin, Volume 2, pp. 66-70

Hair, J.F., Black, W.C., Babin, B.J., Anderson, R.E., 2014. Multivariate Data Analysis. $7^{\text {th }}$ Edition. Essex, United Kingdom: Pearson Education Limited

Hair, J.F., Celsi, M., Money, A.H., Samouel, P., Page, M. J., 2017a. Essentials of Business Research Methods. New York, USA: Routledge

Hair, J.F., Hult, G.T.M., Ringle, C., Sarstedt, M., 2017b. A Primer on Partial Least Squares Structural Equation Modeling (PLS-SEM). 2 ${ }^{\text {nd }}$ Edition. Los Angeles, USA: SAGE Publications

Hair, J.F., Wolfinbarger, M., Bush, R.P., Ortinau, D.J., 2013. Essentials of Marketing Research. $3^{\text {rd }}$ Edition. New York, USA: McGraw-Hill Higher Education

Hallavo, V., 2015. Superior Performance through Supply Chain Fit: A Synthesis. Supply Chain Management: An International Journal, Volume 20(1), pp. 71-82

Koh, S.C.L., Saad, S., Arunachalam, S., 2006. Competing in the $21^{\text {st }}$ Century Supply Chain through Supply Chain Management and Enterprise Resource Planning Integration. International Journal of Physical Distribution \& Logistics Management, Volume 36(6), pp. $455-465$

Krosnick, J.A., Fabrigar, L.R., 1997. Designing Rating Scales for Effective Measurement in Surveys. New York, USA: John Wiley \& Sons, Inc

Kumar, R., 2011. Research Methodology: A Step-by-Step Guide for Beginners. $3^{\text {rd }}$ Edition. Los Angeles, USA: SAGE Publications

Malhotra, N.K., 2010. Marketing Research: An Applied Orientation. $6^{\text {th }}$ Editon. New York, USA: Pearson Education

Mason-Jones, R., Naylor, B., Towill, D.R., 2000. Lean, Agile or Leagile? Matching Your Supply Chain to the Marketplace. International Journal of Production Research, Volume 38(17), pp. 4061-4070

Nakandala, D., Lau, H.C.W., 2019. Innovative Adoption of Hybrid Supply Chain Strategies in Urban Local Fresh Food Supply Chain. Supply Chain Management: An International Journal, Volume 24(2), pp. 241-255

Naylor, B., Naim, M.M., Berry, D., 1999. Leagility: Integrating the Lean and Agile Manufacturing Paradigms in the Total Supply Chain. International Journal of Production Economics, Volume 62(1-2), pp. 107-118

Nunnally, J.C., Bernstein, I., 1994. Psychometric Theory. $3^{\text {rd }}$ Edition. New York, USA: McGrawHill

Nurcahyo, R., Kristihatmoko, P.H., 2010. Implementation of Lean Concepts Using Quality Tools to Reduce Waste of Product Defects. International Journal of Technology, Volume 1(1), pp. 83-92

Ong, C.H., Yusoff, R.Z., Salleh, S.M., R2015. Influence of Brand Experience and Personality on Loyalty Dimensions: Evidence from Successful Malaysian SME Brands. International Journal of Business and Commerce, Volume 4(07), pp. 51-75

Putri, E.P., Chetchotsak, D., Ruangchoenghum, P., Jani, M.A., Hastijanti, R., 2016. Performance Evaluation of Large and Medium Scale Manufacturing Industry Clusters 
in East Java Province, Indonesia. International Journal of Technology, Volume 7(7), pp. 1269-1279

Salim, H.K., Kadhim, H.O., Abdulridha, W.A., 2019. Supply Chain Management Effects on the Tax Information as the Basic Supporting Revenues in Iraq for the Period from 20142018. International Journal of Supply Chain Management, Volume 8(6), pp. 879-883

Saunders, M., Lewis, P., Thornhill, A., 2009. Research Methods for Business Students. $5^{\text {th }}$ Edition. New York, USA: Prentice Hall

Saunders, M., Lewis, P., Thornhill, A., 2016. Research Methods for Business Students. $7^{\text {th }}$ Edition. New York, USA, Pearson Education Limited

Sekaran, U., Bougie, R., 2010. Research Methods for Business: A Skill Building Approach. Great Britain, UK: John Wiley \& Sons

Wibowo, M.A., Sholeh, M.N., 2015. The Analysis of Supply Chain Performance Measurement at Construction Project. Procedia Engineering, Volume 125, pp. 25-31 